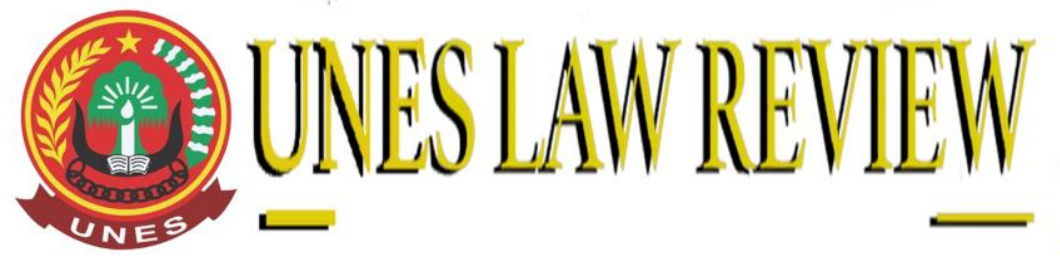

$+6281365118590$

$+6281365118590$

https://review-unes.com/ (7)

uneslawreview@gmail.com @.

DOI: https://doi.org/10.31933/unesrev.v4i3

Diterima: 24/02/2022, Diperbaiki: 25/02/2022, Diterbitkan: 01/03/2022

\title{
KEAMANAN DATA PRIBADI DALAM SISTEM PEMBAYARAN E-WALLET TERHADAP ANCAMAN PENIPUAN DAN PENGELABUAN (CYBERCRIME)
}

\author{
Surya Bodhi ${ }^{1}$, David Tan ${ }^{2}$ \\ ${ }^{1)}$ Fakultas Hukum, Universitas Internasional Batam, Indonesia. \\ Email: 1951106.surya@ uib.edu \\ ${ }^{2)}$ Fakultas Hukum, Universitas Internasional Batam, Indonesia. \\ Email: david.tan@uib.edu
}

Corresponding Author: Surya Bodhi

\section{ABSTRACT}

E-wallet is a digital wallet that is used as a transaction tool in digital form, with the existence of an e-wallet the transaction process is faster and easier in this digitalization era because it only has to scan the QR code. However, behind the efficiency and benefits provided, of course there are risks arising from the use of this e-wallet such as the security of our personal data is threatened. The purpose of this study was to determine law enforcement against cybercrime on $e$-wallet and protection of personal data on e-wallet. The method used in this research is normative research. Based on the principle of legality of cyber crimes such as data theft has violated the ITE Law, therefore a person's personal data must be protected according to the Regulation of the Minister of Communication and Information and Bank Indonesia. According to Philipus M. Hadjon's theory of legal protection, to overcome legal problems such as data theft on e-wallet, preventive and repressive measures are needed.

Keywords: E-wallet, Personal Data protection, Cybercrime

\begin{abstract}
ABSTRAK
E-wallet merupakan dompet digital yang digunakan sebagai alat transaksi dalam bentuk digital, dengan adanya $e$-wallet proses transaksi jadi lebih cepat dan mudah di era digitalisasi ini karena hanya tinggal scan QR code. Namun dibalik efisiensi dan keuntugan yang diberikan, tentunya memiliki resiko yang timbul dari pemakaian $e$-wallet ini seperti terancamnya keamanan data pribadi kita. Tujuan dari penelitian ini adalah untuk mengetahui penegakan hukum terhadap cybercrime pada $e$-wallet serta perlindungan data pribadi pada $e$-wallet. Metode yang digunakan dalam penelitian ini adalah adalah penelitian normatif. Berdasarkan asas legalitas kejahatan cyber seperti pencurian data telah melanggar UU ITE, maka dari itu data pribadi seseorang mesti dilindungi sesuai Peraturan Menkominfo dan Bank Indonesia. Menurut teori perlindungan
\end{abstract}


hukum Philipus M. Hadjon untuk mengatasi masalah hukum seperti pencurian data pada $e$ wallet, diperlukannya sebuah tindakan preventif dan represif.

Kata Kunci: E-wallet, Perlindungan Data Pribadi, Cybercrime

\section{PENDAHULUAN}

Globalisasi saat ini memberikan dampak pada berbagai aspek kehidupan manusia, baik dalam pertumbuhan ekonomi maupun teknologi. Perkembangan tersebut mendorong setiap individu untuk terus melakukan pembaruan dan berusaha untuk dapat memenuhi kebutuhan serta kesejahteraan hidupnya. ${ }^{1}$ Pesatnya perkembangan teknologi tentunya membuat perubahan pola hidup masyarakat menjadi milenium. Berbagai informasi dapat kita ketahui secara langsung di berbagai belahan dunia berkat globalisasi, khususnya pada aspek teknologi yang memberikan manfaat pada masyarakat sehingga dapat melakukan sesuatu dengan mudah, cepat, dan efisien hasil dari inovasi yang dibuat. ${ }^{2}$ Manfaat internet semakin dirasakan oleh pengguna sebagai hal yang tidak terpisahkan dari dunia internet ini. Saat ini masyarakat indonesia telah menggunaakan internet sebagai sarana transaksi jual beli, baik secara tatap muka maupun daring. ${ }^{3}$

Proses perpindahan ke sebuah sistem digital (digitalisasi) telah mengubah aspek kehidupan manusia seperti sistem pembayaran. Sistem pembayaran ialah bagian utama dalam suatu negara karena merupakan hal krusial yang mempengaruhi perkembangan serta pertumbuhan ekonomi negara. ${ }^{4}$ Keefisiensian sebuah sistem pembayaran dapat dilihat dari kapabilitas sebuah negara dalam menghasilkan biaya minimal untuk memperoleh keuntungan dan kelancaran mekanisme dari aktivitas perdagangan karena melibatkan sebuah alat pembayaran yang dijadikan media transaksi dalam siklus perekonomian. ${ }^{5}$ Uang menjadi alat pembayaran utama yang mengalami perkembangan dalam masyarakat, saat ini alat pembayaran uang elektronik (e-money) banyak digunakan oleh masyarakat. Perkembangan e-money di Indonesia adalah perwujudan dari GNNT (gerakan nasional non tunai) dengan maksud meningkatkan apersepsi masyarakat dalam transaksi keuangan dengan menggunakan media pembayaran non tunai. ${ }^{6}$

Dalam PBI No. 20/6/PBI/2018 tentang Uang Elektronik, ada membahas e-money yang merupakan instrument pembayaran, pada dasarnya e-money adalah uang digital yang

\footnotetext{
${ }^{1}$ MA Harahap and S Adeni, 'Tren Penggunaan Media Sosial Selama Pandemi Di Indonesia' (2020) 7 Professional: Jurnal Komunikasi Dan Administrasi Publik 13, 15.

${ }^{2}$ Achmad Nur Fuad Chalimi, Siti Herdinawati and Asadi Asadi, 'Faktor Kemajuan Teknologi Dan Sumber Daya Manusia Terhadap Peningkatan Pendapatan Umkm Era Revolusi 4.0' (2022) 9 Referensi: Jurnal Ilmu Manajemen dan Akuntansi 129, 130.

${ }^{3}$ Mohamad Trio Febriyantoro and Debby Arisandi, 'Pemanfaatan Digital Marketing Bagi Usaha Mikro, Kecil Dan Menengah Pada Era Masyarakat Ekonomi Asean' (2018) 1 Jurnal Riset Manajemen dan Bisnis Dewantara (JMD) 61,62 .

4 Jefry Tarantang and others, 'Perkembangan Sistem Pembayaran Digital Pada Era Revolusi Industri 4.0 Di Indonesia' (2019) 4 Jurnal Al-Qardh 60, 62.

${ }^{5}$ Ibid $; 69$.

6 Ari Syarifudin, 'Pengaruh Keamanan Dan Kemudahan Penggunaan Terhadap Minat Mahasiswa Untuk Menggunakan Dompet Elektronik (E-Wallet)(Studi Kasus Pada Mahasiswa Fakultas Syariah Dan Ekonomi Islam IAIN Syekh Nurjati Cirebon)' (IAIN Syekh Nurjati Cirebon 2021).
} 
disimpan secara elektronik dalam suatu media chip ( dalam bentuk kartu seperti flazz BCA) atau server ( dompet digital seperti Dana, Ovo, dan Go-Pay). ${ }^{7}$ Belakangan ini, layanan dompet digital (e-wallet) muncul dan menjadi tren di Indonesia, dikarenakan semakin banyak penggunaan internet dan smartphone yang terhubungkan $e$-wallet pada sistem pembayaran. ${ }^{8}$ Penggunaan $e$ wallet sangat memudahkan transaksi, apalagi membatasi penggunaan uang tunai di masa pandemi ini. Meski tidak ada informasi yang sah mengenai uang tunai merupakan media transmisi COVID-19, masyarakat tetap melihat uang kotor sebagai jembatan penyebaran virus ini sehingga membuat orang beralih ke pembayaran digital. ${ }^{9}$

Dengan memakai $e$-wallet, masyarakat bisa melakukan transaksi dengan scan kode QR (Quick Response) tanpa harus menggunakan uang tunai. Penggunaan sistem pembayaran QR memang sedang populer saat ini, karena sangat praktis dan mudah digunakan. Pada umumnya, pembayaran QR pada ewallet merupakan cara inovatif yang memberikan kemudahan dalam pengoperasian sistem. Kode QR memiliki keunggulan dalam penyimpanan serta kecepatan pengumpulan data yang akurat dan utilitas fisik yang bertahan lama, Mengingat manfaat dan efektivitas kode QR, Bank Indonesia telah menstandarisasi kode QR yang merupakan teknologi pada saat menggunakan metode pembayaran. ${ }^{10}$ QRIS (Quick Response Code Indonesia Standard) merupakan sebuah standar kode QR dalam sistem pembayaran Indonesia, QRIS ini merupakan produk Bank Indonesia yang dikembangakan bersama Asosiasi Sistem Pembayaran Indonesia (ASPI) dalam rangka penerapan GPN (Gerbang Pembayaran Nasional), yang secara resmi diimplementasikan pada tanggal 1 Januari 2020 silam. ${ }^{11}$

Alasan pembuatan metode pembayaran QRIS ini dilatar belakangi dengan pihak pedagang yang memberikan banyak kode $\mathrm{QR}$ dari berbagai penyedia jasa pembayaran pada saat pelanggan hendak melakukan transaksi cashless, dari situ munculah sebuah tujuan untuk mendorong efisiensi transaksi, melajukan inklusi keuangan, mendorong pertumbuhan ekonomi, dan untuk Indonesia Maju. Pengaturan mengenai QRIS diatur dalam "Peraturan Anggota Dewan Gubernur Nomor 23/8/PADG/2021 tentang Perubahan atas Peraturan Anggota Dewan Gubernur Nomor 21/18/PADG/2019 tentang Implementasi Standar Nasional Quick Response Code untuk Pembayaran." Penggunaan QRIS dapat diterapkan pada aplikasi pembayaran e-wallet yang dijadikan alat pembayaran Server based yang disahkan oleh Bank Indonesia. ${ }^{12}$ Berdasarkan Laporan Rapat Tahunan BI pada 5 November 2021, jumlah masyarakat yang menggunakan QRIS menggapai 12,2 juta. Jumlah ini dapat dikatakan meningkat drastis menjadi 297,1\% dari 22 Maret 2020 yang hanya mencapai 3,08 juta pengguna karena pada pada 5 November 2021

\footnotetext{
${ }^{7}$ Ahyar Ardiansyah, 'Pengaruh Kemudahan Dan Keamanan Data Pribadi Terhadap Minat Menggunakan Dompet Digital (E-Wallet) Linkaja (Studi Kasus Pada Mahasiswa Fakultas Syariah Dan Ekonomi Islam Tahun 2017-2019)' (IAIN Syekh Nurjati Cirebon 2021).

${ }^{8}$ Ahyar Ardiansyah; Loc.Cit.

${ }^{9}$ Fatoni and others, 'Dampak Covid-19 Terhadap Perilaku Konsumen Dalam Penggunaan e-Wallet Di Indonesia' (UIN Sunan Gunung Jati 2020).

${ }^{10}$ Risma Arum Azzahroo and Sri Dwi Estiningrum, 'Preferensi Mahasiswa Dalam Menggunakan Quick Response Code Indonesia Standard (QRIS) Sebagai Teknologi Pembayaran’ (2021) 17 Jurnal Manajemen Motivasi 10, 11.

${ }^{11} \mathrm{Ibid} ; 12$.

${ }^{12}$ Adibah Mumtazah and others, 'Server Based Payment System Indonesia Di Era Revolusi Industry 4.0' (2019) 4 Proceeding of National Conference on Asbis 17, 21.
} 
pedagang mikro yang mendaftar QRIS mencapai 7,53 juta, Pedagang kecil 3,2 juta, dan usaha menengah 928 ribu. $^{13}$

Hal ini menunjukkan bahwa pembayaran yang dilakukan menggunakan QRIS dalam aplikasi $e$-wallet lebih nyaman dan lebih cepat daripada pembayaran konvensional karena menghemat waktu dan uang. Sistem pembayaran berbasis server memang banyak digunakan untuk transaksi dan pembayaran yang dilakukan melalui aplikasi yang ada pada smartphone karena pengguna menganggap metode pembayaran ini bersifat menguntungkan. Pembayaran menggunakan $e$-wallet tidak hanya memberikan tingkat kemudahan dan kecepatan tetapi juga memberi promo atau potongan transaksi. ${ }^{14}$ Saat ini $e$-wallet sudah menyediakan banyak fitur berdasarkan kebutuhan pengguna seperti, pembayaran belanja online dan reguler, pembayaran tagihan, pengiriman uang, hiburan dan lainnya. Hal ini menyebabkan masyarakat semakin tertarik menggunakan $e$-wallet sebagai sarana bertransaksi karena efisiensi serta efektivitasnya. Metode pembayaran QR pada e-wallet cukup mudah dipelajari, dengan sekali click dan arahkan kamera hp untuk scan QRIS, pengguna sudah selesai melakukan transaksi. Menurut Nasution, intensitas penggunaan dan interaksi antara pengguna dengan sistem dapat menunjukan adanya kemudahan ketika menggunakannya. Sebuah sistem atau teknologi yang mempunyai perintah sederhana, dapat memberikan kesan bahwa teknologi sangat mudah dimengerti serta digunakan. $^{15}$

Dilihat dari situasi saat ini dimana semakin banyak masyarakat yang ingin menggunakan sistem pembayaran QRIS dan mengikuti rencana pemerintah untuk melakukan transaksi non tunai, menunjukkan bahwa masyarakat mulai menyadari kemudahan, keuntungan serta manfaat dari metode pembayaran tersebut. Namun dibalik kemudahan dan keuntungan tersebut, ada akibat yang bisa muncul saat menggunakan e-wallet serta ketika melakukan transaksi menggunakan QRIS, seperti yang baru terjadi belakangan ini seorang publik figur yaitu Luna Maya menjadi korban penipuan (scam) saat melakukan transfer uang melalui aplikasi $e$-wallet/ m-banking karena memberitahu pelaku kode One Time Password (OTP) yang menyebabkan korban mengalami kerugian sebesar 1,9 juta rupiah. ${ }^{16}$ Tidak hanya itu, saat ini banyak sekali kejahatan yang muncul dengan memanfaatkan kemajuan teknologi (cybercrime) seperti melakukan peretasan pada akun pengguna (hacking), pengelabuan (phishing), penipuan (scam), dan lain sebagainya untuk melakukan pencurian informasi pribadi pengguna dan informasi pribadi di dalamnya seperti data pribadi, kartu kredit dan informasi saldo keuangan yang merupakan beberapa risiko yang dihadapi $e$-wallet jika pengguna tidak memperhatikan. Secara umum, data pribadi merupakan informasi mengenai identitas individu yang tidak boleh

\footnotetext{
${ }^{13}$ Monavia Ayu Rizaty, 'Jumlah Merchant Terdaftar QRIS Capai 12,2 Juta Hingga November 2021' (Databoks, 2021) <https://databoks.katadata.co.id/datapublish/2021/11/25/jumlah-merchant-terdaftar-qris-capai-122-jutahingga-november-2021> diakses 30 Januari 2022.

${ }^{14}$ Md Wasiul Karim and others, 'Factors Influencing the Use of E-Wallet as a Payment Method among Malaysian Young Adults' (2020) 3 Journal of International Business and Management 1, 2.

${ }^{15}$ Ari Syarifudin; Op.Cit, 7.

${ }^{16}$ Febia Rosada Fitrianum, 'Kronologi Luna Maya Kena Tipu Jutaan Rupiah, Berawal Dari Tawaran Hadiah Rp 800 Ribu' (Tribunnews.com, 2022) <https://www.tribunnews.com/seleb/2022/02/02/kronologi-luna-maya-kena-tipujutaan-rupiah-berawal-dari-tawaran-hadiah-rp-800-ribu> diakses 3 Februari 2022.
} 
disebarluaskan tanpa izin si pemilik informasi karena bisa disalahgunakan oleh oknum yang tidak bertanggungjawab. ${ }^{17}$ Berdasarkan penjelasan di atas maka timbulah rumusan masalah dalam penelitian ini yaitu, bagaimana penegakan hukum terhadap kejahatan cyber pada $e$-wallet serta bagaimana perlindungan hukum terhadap keamanan data pengguna dalam ancaman pencurian data. Dengan tujuan untuk mengetahui penegakan hukum terhadap cybercrime pada $e$ wallet serta perlindungan data pribadi pada $e$-wallet.

\section{METODE PENELITIAN}

Jenis penelitian dalam penulisan ini merupakan penelitian hukum normatif dengan menggunakan metode literatur atau kepustakaan. Penelitian hukum normatif pada hakikatnya adalah studi dokumen yang meneliti dan mengkaji sumber bahan hukum primer berupa peraturan tertulis seperti Undang-Undang ITE, Peraturan Bank Indonesia, Peraturan Menkominfo, teori hukum, pendapat para ahli, serta bahan hukum sekunder berupa publikasi tentang keamanan $e$ wallet dan hukum yang meliputi hasil penelitian jurnal, artikel, dan jenis tulisan lainnya yang mempunyai relevansi langsung terkait permasalahan dalam penelitian ini. ${ }^{18}$ Analisis data yang digunakan dalam penelitian ini adalah teknik analisis data kualitatif yang merupakan metode analisis data dengan cara mengeksplorasi makna serta pemahaman dari suatu fenomena dan dihubungkan dengan teori dari studi kepustakaan dan pendekatan perundang-undangan menurut kualitas serta kebenarannya yang kemudian disusun menjadi satu kesatuan sistematis yang kemudian ditarik kesimpulan sehingga dapat menjawab rumusan masalah dalam penelitian ini dengan metode penulisan deduktif. ${ }^{19}$

\section{HASIL DAN PEMBAHASAN}

\section{Penegakan Hukum terhadap Kejahatan Cyber pada E-wallet}

Perkembangan teknologi yang semakin maju perkembangannya, baik perangkat maupun pemanfaatannya, memberikan nilai positif bagi kehidupan masyarakat seperti dihadirkannya $e$ wallet. E-wallet yang merupakan layanan program yang memiliki fungsi mengarsip dan memonitor informasi belanja online pengguna, seperti data login pengguna, kata sandi, alamat pengiriman, dan informasi mengenai kartu kredit pengguna. ${ }^{20}$ Dengan adanya $e$-wallet tentunya akan memudahkan setiap orang ketika hendak melakukan transaksi. Teknologi tidak hanya menawarkan keuntungan dengan mempermudah kehidupan masyarakat, tetapi juga memiliki kelemahan yaitu memudahkan para penjahat untuk melakukan kejahatan. Seiring berjalannya waktu, bentuk kejahatan semakin beragam. Perkembangan teknologi merupakan salah satu faktor yang dapat memicu terjadinya kejahatan. Seiring dengan perkembangan teknologi, jenis kejahatan juga itu berkembang dan beragam. Banyak kejahatan baru bermunculan seiring dengan perkembangan teknologi, khususnya teknologi internet. cybercrime merupakan sebuah bentuk

\footnotetext{
${ }^{17}$ Muhamad Hasan Rumlus and Hanif Hartadi, 'Kebijakan Penanggulangan Pencurian Data Pribadi Dalam Media Elektronik' (2020) 11 Jurnal HAM 285, 286.

${ }^{18}$ Muhaimin, Metode Penelitian Hukum (Mataram University Prees 2020) 48.

19 David Tan, 'Metode Penelitian Hukum: Mengupas Dan Mengulas Metodologi Dalam Menyelenggarakan Penelitian Hukum' (2021) 8 NUSANTARA: Jurnal Ilmu Pengetahuan Sosial 2463, 2475.

${ }^{20}$ Fatoni and others; Op.Cit.
} 
dari kejahatan yang dikarenakan oleh perkembangan teknologi, Kejahatan ini telah menjadi perhatian dunia internasional. cybercrime merupakan salah satu sisi gelap kemajuan teknologi yang berdampak negatif pada setiap bidang kehidupan modern saat ini. ${ }^{21}$ Pada hakikatnya Cybercrime adalah tindakan ilegal yang dilakukan dengan menggunakan internet, kecanggihan teknologi, dan telekomunikasi dalam melakukan sebuah aksi kejahatan.

David S.Wall menyebutkan "kejahatan dunia maya secara luas menggambarkan kejahatan yang terjadi di dalam ruang itu dan istilah itu telah datang untuk melambangkan ketidakamanan dan risiko online". ${ }^{22}$ Kasus pencurian data pengguna $e$-wallet dapat terjadi sebagai akibat dari penipuan (scam) maupun pengelabuan (phishing) yang dilakukan oleh para pelaku. Dalam hal ini pelaku pembobolan data dapat dianggap telah melakukan tindak pidana sehingga diperlukan penegakan hukum pidana. Hukum pidana adalah bagian dari hukum publik, hukum Pidana dapat didefinisikan sebagai aturan yang merupakan tindakan subjek hukum, yang menetapkan hak dan kewajiban, apa yang dapat atau mungkin tidak dilakukan individu, dan juga hukuman atas pelanggaran tersebut. Dalam sistem hukum Indonesia, penetapan suatu perbuatan sebagai tindak pidana didasarkan pada prinsip legalitas, di mana pelaku suatu perbuatan dapat dikenakan sanksi berdasarkan peraturan tertulis yang berlaku. Prinsip legalitas tersebut jelas tertuang dalam Pasal 1 (1) KUHP yang saat ini berlaku. Para pelaku, melakukan tindakan kriminal sedemikian rupa sehingga korban memberikan OTP kepada pelaku, dan mereka dapat dengan mudah mengakses akun $e$-wallet milik korban, tindakan seperti itu biasanya awali dengan phishing. ${ }^{23}$

Phishing adalah upaya penipuan untuk memperoleh informasi sensitif, seperti nama pengguna, kata sandi, dan detail kartu kredit, dengan menyamarkannya sebagai situs yang dapat dipercaya dalam komunikasi elektronik. ${ }^{24}$ Phishing biasanya dilakukan melalui e-mail atau melalui pesan instan, dan sering mengarahkan pengguna untuk memasukkan rincian situs web, meskipun kontak telepon juga telah digunakan pada banyak waktu. Berdasarkan sistem hukum Indonesia, tindakan pelaku dalam mengakses akun korban secara ilegal dapat memenuhi syarat sebagai pelanggaran Pasal 30 ayat (1) dan (2) "Undang-Undang No. 11 Tahun 2008 Tentang Informasi dan Transaksi Elektronik" (Selanjutnya disebut UU ITE). yang menyatakan "Setiap Orang dengan sengaja dan tanpa hak atau melawan hukum, mengakses Komputer dan/atau Sistem Elektronik milik Orang lain dengan cara apa pun " dalam ayat (2) "Setiap orang dengan sengaja dan tanpa hak atau melawan hukum, mengakses Komputer dan/atau Sistem Elektronik dengan cara apa pun dengan tujuan memperoleh Informasi Elektronik dan/atau Dokumen Elektronik ". Lanjut dalam Pasal 46 ada menyebutkan bahwa orang yang melanggar pasal 30 ayat (1) atau ayat (2) akan dipidana dengan pidana penjara paling lama 7 tahun dan/atau denda

${ }^{21}$ Raodia Raodia, 'Pengaruh Perkembangan Teknologi Terhadap Terjadinya Kejahatan Mayantara (Cybercrime)' (2019) 6 Jurisprudentie: Jurusan Ilmu Hukum Fakultas Syariah dan Hukum 230, 234.

${ }^{22}$ Rahel Octora, P Lindawat S.Sewu and Jason Arnold Sugiono, 'Regulation on Electronic System Security for EWallet in Order to Protect Consumers from Financial Loss Due to Cyber Fraud Based on Indonesian Law' (2021) 4 International Journal of Social Science And Human Research 2272. 2277.

${ }^{23}$ Loc. Cit.

${ }^{24}$ Saputra Gulo and others, 'Cyber Crime Dalam Bentuk Phising Berdasarkan Undang-Undang Informasi Dan Transaksi Elektronik’ (2020) 1 PAMPAS: Journal Of Criminal 68, 70. 
paling banyak Rp.700.000.000,00. ${ }^{25}$ Walaupun memiliki peraturan dan undang-undang yang mengatur tindakan pencurian data, di Indonesia masih belum mempunyai regulasi khusus yang mengatur $e$-wallet, sehingga dapat menimbulkan konflik jika ada ada peraturan terkait yang digunakan sebagai dasar hukum ketika ada masalah hukum. Meskipun ada pengaturan yang mirip dengan $e$-wallet, undang-undang dan legislatif yang mengatur $e$-wallet masih tetap diperlukan, karena $e$-wallet dan $e$-money bukanlah hal yang sama.

\section{Perlindungan Hukum terhadap Keamanan Data Pribadi pada $E$-wallet}

Dalam Pasal 1 (1) Peraturan Menkominfo No. 20 Tahun 2016 tentang Perlindungan Data Pribadi Dalam Sistem Elektronik, Data pribadi adalah data perseorangan tertentu yang disimpan, dirawat dan dijaga kebenaran serta dilindungi kerahasiaannya. ${ }^{26}$ Philipus $M$. Hadjon memberikan pandangan bahwa perlindungan hukum merupakan perlindungan akan "harkat dan martabat" Serta pengakuan terhadap hak asasi manusia yang dimiliki oleh sebuah subjek hukum. ${ }^{27}$ Memberikan perlindungan kepada masyarakat merupakan tujuan dari pada hukum, hukum merupakan sarana pamungkas untuk mengendalikan berbagai perubahan dalam masyarakat agar perubahan yang ada juga dapat mewujudkan pembangunan bangsa dan negara ke arah yang lebih baik. Undang-undang dapat memberikan solusi untuk menggunakan dan memanfaatkan ilmu pengetahuan dan teknologi sebaik mungkin untuk manfaat dan kelangsungan hidup manusia, dalam konteks transaksi elektronik, hukum memiliki tujuan adalah melindungi konsumen. ${ }^{28}$ Jika konsumen adalah masyarakat, berarti melindungi konsumen berarti juga melindungi masyarakat. Salah satu bentuk perlindungan yang sah bagi konsumen $e$-wallet adalah dengan menjaga keamanan data pribadinya. Perlindungan hukum merupakan proteksi akan hak asasi manusia yang dilanggar oleh orang lain dan perlindungan ini diberikan kepada masyarakat supaya dapat menikmati semua hak yang diberikan oleh undang-undang kepada mereka. Berdasarkan konsep privasi dari data tentang seseorang "privacy of data about person", yang berarti hak privasi juga dapat berhubungan dengan informasi tentang seseorang yang dikumpulkan dan digunakan oleh orang lain. ${ }^{29}$ Dari konsep tersebut kita mengetahui bahwa melindungi keamanan data pribadi adalah perwujudan privasi seseorang sehingga sangat penting.

Philipus M. Hadjon mengungkapkan 2 jenis perlindungan hukum yang dapat diberikan yaitu, preventive and repressive legal protection (Preventif dan represif). ${ }^{30}$ Perlindungan data pribadi pada $e$-wallet haruslah dilakukan pada pihak penyedia pada saat menerima dan mendapatkan data pengguna, lalu pada saat mengolah, menganalisis, menyimpan dan menampilkan data pengguna yang sudah di terima, dan apabila ada kepentingan untuk

\footnotetext{
${ }^{25}$ Undang-Undang Nomor 11 Tahun 2008 tentang Informasi dan Transaksi Elektronik

${ }^{26}$ Peraturan Menkominfo No. 20 Tahun 2016 tentang Perlindungan Data Pribadi Dalam Sistem Elektronik

${ }^{27}$ Roberto Ranto, 'Tinjauan Yuridis Perlindungan Hukum Terhadap Konsumen Dalam Transaksi Jual Beli Melalui Media Elektronik' (2019) 2 Jurnal Ilmu Hukum: ALETHEA 145, 147.

28 Kornelius Benuf, Siti Mahmudah and Ery Agus Priyono, 'Perlindungan Hukum Terhadap Keamanan Data Konsumen Financial Technology Di Indonesia’ (2019) 3 Refleksi Hukum: Jurnal Ilmu Hukum 145, 154.

${ }^{29}$ Ibid; 155.

${ }^{30} \mathrm{Ni}$ Nyoman Anita Candrawati, 'Perlindungan Hukum Terhadap Pemegang Kartu E-Money Sebagai Alat Pembayaran Dalam Transaksi Komersial’ (2014) 1 Volksgeist: Jurnal Ilmu Hukum dan Konstitusi 1, 11.
} 
penyebarluasan serta pemusnahan data pribadi pengguna maka perlindungan terhadap proses data tersebut harus dipastikan keamanannya. ${ }^{31}$ Hal tersebut diperkuat dalam penjelasannya Pasal 26 UU ITE yang menjelaskan bahwa data pribadi adalah hak pribadi seseorang. Hak yang dimaksud dalam pasal tersebut terdiri dari hak atas kerahasiaan data, pengaduan dalam rangka penyelesaian sengketa terkait data pribadi karena penyelenggara sistem elektronik tidak menjaga kerahasiaan data pribadi, dan memiliki hak untuk mengakses atau dapat mengubah atau memperbarui data pribadi mereka tanpa mengganggu sistem pengelolaan data pribadi. ${ }^{32}$. Jika hendak menggunakan informasi dari sarana elektronik dan informasi tersebut memiliki kaitannya dengan data pribadi seseorang, maka harus memperoleh izin dan persetujuan orang yang bersangkutan, apabila ada pihak yang melanggar aturan ini, dapat digugat atas kerugian yang diakibatkannya. Berdasarkan isi dari pasal tersebut kegiatan seperti pengumpulan dan penyebarluasan data pribadi merupakan pelanggaran terhadap hak privasi seseorang, karena hak privasi mencakup hak untuk memutuskan apakah akan memberikan data pribadi atau tidak. Pengguna sistem elektronik memiliki kewajiban untuk menjaga kerahasiaan data pribadi yang diperoleh, dikumpulkan, diolah, dan analisi, serta melindungi data pribadi dan dokumen yang berisi data pribadi tersebut dari penyalahgunaan; dan bertanggung jawab atas data pribadi yang terkandung dalam kendalinya, jaminan perlindungan data sudah diatur dalam Pasal 15 ayat (1) UU ITE, yang mengharuskan setiap penyelenggara sistem elektronik untuk menjaga keamanan platform. $^{33}$

Bank Indonesia (BI) sebagai pengawas kegiatan sistem pembayaran di Indonesia, memiliki kewajiban untuk mengawasi transaksi pembayaran melalui kebijakan yang sudah ditentukan, untuk tujuan efisiensi dan keamanan dalam sistem pembayaran. ${ }^{34}$ Hal ini dapat dilakukan dengan memantau sistem yang ada dan pada tahap perencanaan, melakukan penilaian tentang bagaimana setiap penyelenggara akan melakukan kegiatan sistem pembayaran berdasarkan kepatuhan terhadap tujuan, keamanan, dan efisiensi setiap sistem pembayaran. Dalam Pasal 20 Ayat (2) PBI Nomor 18/40/PBI/2016 tentang Penyelenggaraan Pemrosesan Transaksi Pembayaran, memuat ketentuan mengenai penerapan standar keamanan sistem informasi agar tujuan penyelenggaraan sistem pembayaran di Indonesia yang bercirikan prinsip efisiensi, fluiditas, keamanan, dan Keandalan dapat dilakukan dengan benar. ${ }^{35}$ Setelah berlakunya PBI No. 20/6/PBI/2018 tentang Uang Elektronik, diberlakukannya kebijakan dimana pihak yang beraksi sebagai penyelenggara harus terlebih dahulu memperoleh izin dari BI, dengan cara memenuhi persyaratan umum dan aspek kelayakan. Dalam Pasal 34 PBI

31 AA Ngurah Deddy Hendra Kesuma, I Nyoman Putu Budiartha and Puru Ayu Sriasih Wesna, 'Perlindungan Hukum Terhadap Keamanan Data Pribadi Konsumen Teknologi Finansial Dalam Transaksi Elektronik’ (2021) 2 Jurnal Preferensi Hukum 411, 413.

${ }^{32}$ Undang-Undang Nomor 19 Tahun 2016 tentang Perubahan Atas Undang-Undang Nomor 11 Tahun 2008 tentang Informasi dan Transaksi Elektronik

${ }^{33}$ Ririn Aswandi, Purti Rofifah Nabilah Muchin and Muhammad Sultan, 'Perlindungan Data Dan Informasi Pribadi Melalui Indonesian Data Protection System (Idps)' (2020) 3 Jurnal Legislatif 167,170.

${ }^{34}$ Elsa Debora Manurung, Lastuti Abu Bakar and Tri Handayani, 'Kepastian Hukum Dalam Penyelenggaraan Layanan Dompet Elektronik Dalam Sistem Pembayaran Dikaitkan Dengan Prinsip Lancar, Aman, Efisien, Dan Andal Berdasarkan PBI Nomor 20/6/PBI/2018 Tentang Uang Elektronik' (2020) 10 Jurnal Jurisprudence 35, 37.

${ }^{35}$ Ibid; 42. 
menyatakan bahwa pihak penyelenggara harus menerapkan standar keamanan pada sistem informasi serta penyelenggara uang elektronik diwajibkan untuk menerapkan prinsip anti pencucian uang, pencegahan pendanaan terorisme, dan perlindungan konsumen agar dapat menciptakan kepastian hukum bagi pengguna. ${ }^{36}$

Keberadaan OJK sebagai kustodian di sektor jasa keuangan seharusnya dapat melindungi konsumen dari pelaku usaha jasa keuangan yang dianggap merugikan kepentingan konsumen. Dalam Pasal 4 UU No. 21 Tahun 2011 tentang Otoritas Jasa Keuangan ada menjelaskan tujuan pembentukan OJK, salah satu tujuan utamanya adalah melindungi kepentingan konsumen dan masyarakat, ${ }^{37}$ agar konsumen merasa aman ketika menggunakan jasa keuangan. OJK sebagai lembaga yang berwenang mengawasi kegiatan usaha di sektor jasa keuangan harus dapat melindungi konsumen pengguna jasa keuangan yang menempatkan dananya dan/atau memanfaatkan layanan yang tersedia di lembaga jasa keuangan. Oleh karena itu, OJK melalui "Surat Edaran OJK Nomor 18 /SEOJK.02/2017 Tentang Tata Kelola Dan Manajemen Risiko Teknologi Informasi Pada Layanan Pinjam Meminjam Uang Berbasis Teknologi Informasi”Ada menjelaskan bahwa data pribadi yang mesti dilindungi yaitu nama pengguna, alamat tinggal, kartu identitas (Seperti KTP, SIM, Paspor, dan NPWP), tanggal lahir, email pengguna, IP address, nomor telepon pengguna, nomor rekening, nama ibu kandung, nomor kartu kredit, identitas digital (biometrik), tanda tangan, riwayat pendidikan, riwayat pekerjaan, rekening koran, daftar harta kekayaan, data dan informasi terkait lainnya. ${ }^{38}$ Tetapi masih banyak masyarakat yang hanya menerima informasi namun tidak dapat memahami serta mengolahnya dengan benar, sehingga masih banyak masyarakat yang menelaah informasi yang tidak akurat.

Supaya data pribadi pada e-wallet bisa tetap aman, maka diperlukannya tindakan preventif untuk mencegah dampak negatif serta penyalahgunaan dari penggunaan teknologi. Menurut Kominfo tindakan untuk mencegah kejahatan cyber terjadi ialah tidak sembarangan memberikan kode OTP. Kode OTP merupakan hal paling krusial dalam keamanan teknologi saat ini, karena kode OTP sama halnya seperti kunci rumah yang tidak bisa di kasih ke sembarang orang. Jika seseorang menerima SMS, telepon, email, bahkan chat dari institusi resmi atau penyedia $e$-wallet yang isinya meminta kode OTP maka harus diwaspadai, karena institusi yang sebenarnya tidak akan pernah meminta kode OTP. Selain itu, Kominfo juga menghimbau kepada masyarakat untuk selalu waspada terhadap website palsu atau penipuan dan melakukan kecurangan menggunakan call forwarding. Rekomendasi Kominfo yang pertama ialah segera hubungi call center aplikasi uang elektronik atau m-banking terkait untuk pengaduan dan penangannya setelah itu kita mesti melaporkan pada pihak yang berwenangan seperti pihak Bank Indonesia, kepolisian, OJK dan institusi terkait untuk melakukan pelaporan serta penyelidikan. Selain tidak memberikan kode OTP sembarangan, untuk terjadinya cybercrime bisa dimulai dari kita dengan cara meningkatkan pemahaman mengenai pentingnya keamanan data pribadi. Dengan pahamnya masyarakat mengenai keamanan data, maka masalah cybercrime yang

\footnotetext{
${ }^{36}$ Richo Fernando Sitorus, 'Perlindungan Hukum Pemegang Kartu Uang Elektronik Ketika Hilang' (2018) 5 Novum: Jurnal Hukum 179, 181.

${ }^{37}$ Undang-Undang No. 21 Tahun 2011 tentang Otoritas Jasa Keuangan

${ }^{38}$ Kornelius Benuf, Op.Cit; 156.
} 
menimpah masyarakat akan berkurang. Jika sudah ada tindakan preventif dan represif yang diberikan tetapi dari masyarakat tidak mau peduli serta mengabaikan hal tersebut, maka masalah keamanan data pribadi tidak akan ada habisnya dan tetap akan berlanjut terus. ${ }^{39}$

\section{KESIMPULAN}

1. Perkembangan teknologi yang semakin hari semakin maju, baik perangkat maupun penggunaannya, membawa dampak positif bagi kehidupan masyarakat seperti dihadirkannya $e$-wallet, tetapi penggunaan dan pemanfaatan teknologi yang meluas juga dapat menciptakan dimensi baru kejahatan seperti scam dan phishing yang memanfaat kemajuan teknologi untuk melakukan tindakan kejahatan untuk memperoleh informasi sensitif seseorang. Walaupun ada peraturan dan undang-undang yang mengatur mengenai pencurian data, tetapi tidak ada undang-undang dan legislatif yang mengawasi $e$-wallet.

2. Sebenarnya kejahatan cyber bukan tidak mungkin untuk diatasi, namun ada keterbatasan yang dimiliki pihak berwajib untuk menemukan titik temu yang dapat mencegah serta mengatasi kejahatan cyber. Kurangnya pemahaman terhadap pentingnya keamanan data pribadi juga menjadi hal krusial terhadap maraknya kejahatan ini. Pembayaran $e$-wallet yang menggunakan QRIS memiliki tujuannya untuk memudahkan pembayaran transaksi serta meminimalisir kebocoran data pribadi kita, tetapi hal ini tidak menjamin data kita aman dari modus pencurian data yang terjadi saat ini. Walaupun memiliki resiko seperti kebocoran data, penggunaan $e$-wallet masih tetap banyak peminatnya, karena sudah menjadi bagian dari kehidupan dan transaksi pembayaran di era digitalisasi ini. Meskipun begitu, pihak penyedia jasa $e$-wallet harus tetap memperhatikan ketentuan mengenai keamanan data pribadi pengguna agar masyarakat bisa tetap aman dan nyaman ketika menggunakannya.

\section{DAFTAR PUSTAKA}

Muhaimin, Metode Penelitian Hukum (Mataram University Press 2020)

Fitrianum FR, 'Kronologi Luna Maya Kena Tipu Jutaan Rupiah, Berawal Dari Tawaran Hadiah Rp $800 \quad$ Ribu' (Tribunnews.com, 2022) $<$ https://www.tribunnews.com/seleb/2022/02/02/kronologi-luna-maya-kena-tipu-jutaanrupiah-berawal-dari-tawaran-hadiah-rp-800-ribu> diakses 3 Februari 2022

Rizaty MA, 'Jumlah Merchant Terdaftar QRIS Capai 12,2 Juta Hingga November 2021' (Databoks, 2021) <https://databoks.katadata.co.id/datapublish/2021/11/25/jumlahmerchant-terdaftar-qris-capai-122-juta-hingga-november-2021> diakses 30 Januari 2022

Hafis F, 'Apa Yang Harus Dilakukan Jika Jadi Korban Penipuan Online? Ini Solusi Kominfo' (kominfo.go.id, 2020) <https://www.kominfo.go.id/content/detail/27912/apa-yang-harusdilakukan-jika-jadi-korban-penipuan-online-ini-solusi-kominfo/0/sorotan_media> diakses 7 Februari 2022

\footnotetext{
${ }^{39}$ Faisal Hafis, 'Apa Yang Harus Dilakukan Jika Jadi Korban Penipuan Online? Ini Solusi Kominfo' (kominfo.go.id, 2020) <https://www.kominfo.go.id/content/detail/27912/apa-yang-harus-dilakukan-jika-jadi-korban-penipuanonline-ini-solusi-kominfo/0/sorotan_media>diakses 7 Februari 2022.
} 
Aswandi R, Muchin PRN and Sultan M, 'Perlindungan Data Dan Informasi Pribadi Melalui Indonesian Data Protection System (Idps)’ (2020) 3 Jurnal Legislatif 167

Azzahroo RA and Estiningrum SD, 'Preferensi Mahasiswa Dalam Menggunakan Quick Response Code Indonesia Standard (QRIS) Sebagai Teknologi Pembayaran’ (2021) 17 Jurnal Manajemen Motivasi 10

Benuf K, Mahmudah S and Priyono EA, 'Perlindungan Hukum Terhadap Keamanan Data Konsumen Financial Technology Di Indonesia' (2019) 3 Refleksi Hukum: Jurnal Ilmu Hukum 145

Candrawati NNA, 'Perlindungan Hukum Terhadap Pemegang Kartu E-Money Sebagai Alat Pembayaran Dalam Transaksi Komersial' (2014) 1 Volksgeist: Jurnal Ilmu Hukum dan Konstitusi 1

Chalimi ANF, Herdinawati S and Asadi A, 'Faktor Kemajuan Teknologi Dan Sumber Daya Manusia Terhadap Peningkatan Pendapatan Umkm Era Revolusi 4.0' (2022) 9 Referensi: Jurnal Ilmu Manajemen dan Akuntansi 129

Febriyantoro MT and Arisandi D, 'Pemanfaatan Digital Marketing Bagi Usaha Mikro, Kecil Dan Menengah Pada Era Masyarakat Ekonomi Asean' (2018) 1 Jurnal Riset Manajemen dan Bisnis Dewantara (JMD) 61

Gulo S and others, 'Cyber Crime Dalam Bentuk Phising Berdasarkan Undang-Undang Informasi Dan Transaksi Elektronik' (2020) 1 PAMPAS: Journal Of Criminal 68

Harahap MA and Adeni S, 'Tren Penggunaan Media Sosial Selama Pandemi Di Indonesia' (2020) 7 Professional: Jurnal Komunikasi Dan Administrasi Publik 13

Karim MW and others, 'Factors Influencing the Use of E-Wallet as a Payment Method among Malaysian Young Adults' (2020) 3 Journal of International Business and Management 1

Kesuma AANDH, Budiartha INP and Wesna PAS, 'Perlindungan Hukum Terhadap Keamanan Data Pribadi Konsumen Teknologi Finansial Dalam Transaksi Elektronik’ (2021) 2 Jurnal Preferensi Hukum 411

Manurung ED, Bakar LA and Handayani T, 'Kepastian Hukum Dalam Penyelenggaraan Layanan Dompet Elektronik Dalam Sistem Pembayaran Dikaitkan Dengan Prinsip Lancar, Aman, Efisien, Dan Andal Berdasarkan PBI Nomor 20/6/PBI/2018 Tentang Uang Elektronik’ (2020) 10 Jurnal Jurisprudence 35

Mumtazah A and others, 'Server Based Payment System Indonesia Di Era Revolusi Industry 4.0' (2019) 4 Proceeding of National Conference on Asbis 17

Octora R, S.Sewu PL and Sugiono JA, 'Regulation on Electronic System Security for E-Wallet in Order to Protect Consumers from Financial Loss Due to Cyber Fraud Based on Indonesian Law' (2021) 4 International Journal of Social Science And Human Research 2272

Ranto R, 'Tinjauan Yuridis Perlindungan Hukum Terhadap Konsumen Dalam Transaksi Jual Beli Melalui Media Elektronik’ (2019) 2 Jurnal Ilmu Hukum: ALETHEA 145 
Raodia R, 'Pengaruh Perkembangan Teknologi Terhadap Terjadinya Kejahatan Mayantara (Cybercrime)' (2019) 6 Jurisprudentie: Jurusan Ilmu Hukum Fakultas Syariah dan Hukum 230

Rumlus MH and Hartadi H, 'Kebijakan Penanggulangan Pencurian Data Pribadi Dalam Media Elektronik' (2020) 11 Jurnal HAM 285

Sitorus RF, 'Perlindungan Hukum Pemegang Kartu Uang Elektronik Ketika Hilang' (2018) 5 Novum: Jurnal Hukum 179

Tan D, 'Metode Penelitian Hukum: Mengupas Dan Mengulas Metodologi Dalam Menyelenggarakan Penelitian Hukum' (2021) 8 NUSANTARA: Jurnal Ilmu Pengetahuan Sosial 2463

Tarantang J and others, 'Perkembangan Sistem Pembayaran Digital Pada Era Revolusi Industri 4.0 Di Indonesia' (2019) 4 Jurnal Al-Qardh 60

Ardiansyah A, 'Pengaruh Kemudahan Dan Keamanan Data Pribadi Terhadap Minat Menggunakan Dompet Digital (E-Wallet) Linkaja (Studi Kasus Pada Mahasiswa Fakultas Syariah Dan Ekonomi Islam Tahun 2017-2019)' (IAIN Syekh Nurjati Cirebon 2021)

Fatoni and others, 'Dampak Covid-19 Terhadap Perilaku Konsumen Dalam Penggunaan eWallet Di Indonesia’ (UIN Sunan Gunung Jati 2020)

Syarifudin A, 'Pengaruh Keamanan Dan Kemudahan Penggunaan Terhadap Minat Mahasiswa Untuk Menggunakan Dompet Elektronik (E-Wallet)(Studi Kasus Pada Mahasiswa Fakultas Syariah Dan Ekonomi Islam IAIN Syekh Nurjati Cirebon)' (IAIN Syekh Nurjati Cirebon 2021)

Peraturan Menkominfo No. 20 Tahun 2016 tentang Perlindungan Data Pribadi Dalam Sistem Elektronik

Undang-Undang Nomor 11 Tahun 2008 tentang Informasi dan Transaksi Elektronik

Undang-Undang No. 21 Tahun 2011 tentang Otoritas Jasa Keuangan 